DOI: $10.19195 / 2300-7729.35 .5$

\author{
MARIA MAtGORZATA MACZKOWSKA \\ NU Univerzitetska Biblioteka \\ „Sv. Kliment Ohridski”, Bitola, Macedonia
}

\title{
Implementacja systemu COBISS w bibliotekach bałkańskich
}

We współczesnym świecie biblioteki są centrami wiedzy, a ich zadaniem jest ewidencja, gromadzenie i udostępnianie wyników zdobyczy intelektualnych społeczeństw. Roli tej nie mogłyby realizować, gdyby ich funkcjonowanie nie było wspierane nowymi technologiami informatycznymi i komunikacyjnymi. Biblioteki nie mogą jednak funkcjonować odizolowane od siebie, powinny się integrować, a tym samym stworzyć warunki dialogu i współpracy, które są podstawą rozwoju każdego państwa i całej wspólnoty międzynarodowej.

Międzynarodowa Federacja Bibliotekarskich Stowarzyszeń i Instytucji (IFLA), planując unowocześnienie pracy bibliotek i rozwinięcie współpracy pomiędzy bibliotekami, wydała w 1971 r. standardy ISBD (International Standard Bibliographic Description), dotyczące opisu i identyfikacji zbiorów bibliotecznych ${ }^{1}$. Standardy te umożliwiły ujednolicenie opracowania zbiorów i lepszą wymianę informacji bibliotecznych. Dzięki ustalonemu porządkowi elementów przewidzianych w opisie zbiorów bibliotecznych znikały bariery językowe, co pozwoliło, by standardy ISBD zostały zaakceptowane w centrach bibliotekarskich na świecie.

Biblioteki jugosłowiańskie również wykorzystywały standardowy opis bibliograficzny ISBD przy opracowywaniu swoich zbiorów od momentu jego wprowadzenia. Do 1961 r. wszystkie prace nad stworzeniem ujednoliconych zasad katalogowania odbywały się w granicach pojedynczych republik.

W Chorwacji już w latach 30. XX w. zapoczątkowano prace nad zasadami tworzenia katalogów alfabetycznych Biblioteki Narodowej i Uniwersyteckiej w Zagrzebiu (Nacionalna i sveučilišna biblioteka). Stworzony wówczas regulamin był stopniowo dopracowywany, a po II wojnie światowej wykorzystany w wielu bibliotekach Republiki jako wzór pomocny przy tworzeniu katalogów.

${ }^{1} I S B D(M)$ - Meǵgunaroden standarden bibliografski opis za monografski publikacii, red. L. Gjuzelova Hadži Boškova, Skopje 1975, s. 5. 
W Słowenii zaraz po zakończeniu wojny, w 1947 r., wydany został regulamin opracowywania zbiorów, przeznaczony dla większości bibliotek Pravila za katalogizacijo v znanstvenih knjižnicah. I. Abecedni imenski katalog.

W tym samym czasie opracowano zasady katalogowania w Bibliotece Narodowej i w Bibliotece Uniwersyteckiej im. Svetozara Markovicia w Belgradzie. Prace nad regulaminem opracowania zbiorów zostały uwieńczone wydaniem w 1957 r. opracowania zbiorowego pod tytułem Univerzitet u Beogradu. Narodna bibloteka u Beogradu. Pravila za katalogizaciju. Zawarte w nim zasady katalogowania zostały zaakceptowane przez wszystkie biblioteki Serbii, a także wykorzystane w bibliotekach Bośni i Hercegowiny, Czarnogóry i Macedonii.

W 1961 r. Związek Towarzystw Bibliotekarskich Jugosławii podjął decyzję o wydaniu jugosłowiańskiego podręcznika zasad katalogowania. W 1970 r. ukazał się Pravilnik i priručnik za izradbu abecednih kataloga, zaakceptowany przez wszystkie biblioteki jugosłowiańskie. Drugie wydanie tej książki z 1984 r. zostało poprawione i uzupełnione o nowo przyjęte standardy ISBD 2 .

Wraz z pojawieniem się i wykorzystaniem w bibliotekach komputerów, standardy biblioteczno-bibliograficzne stały się podstawą do utworzenia zautomatyzowanych baz informacji. W latach 80 . XX w., kierując się ustaleniami zawartymi w programach UNESCO (NATIS — National Information System, UNISIST United Nations Information System in Science and Technology, GIP — General Information Programme), przystąpiono w Jugosławii do utworzenia narodowego programu biblioteczno-informacyjnego BIS (Bibliotečno-informativen sistem) oraz systemu informacji naukowych i technologicznych SNTIJ (Sistem na naučno-tehnološki informacii na Jugoslavija) ${ }^{3}$.

Zorganizowanie systemu biblioteczno-informacyjnego jako części społecznego systemu informacji OSI (Opštestven sistem na informiranje) miało na celu zaspokojenie potrzeb łatwego dostępu użytkowników do informacji, a także zracjonalizowanie pracy bibliotecznej wszystkich uczestników systemu oraz stworzenie warunków szybkiego rozwoju i postępu bibliotekarstwa.

System SNTIJ miał umożliwić gromadzenie, przetwarzanie i transfer informacji z zakresu nauki i technologii. System ten pozwolił na stworzenie jugosłowiańskiej bazy informacyjnej JUBIB, to znaczy stworzenie wspólnego katalogu całego bogactwa książkowego, jakim dysponowała każda republika, a tym samym każda biblioteka będąca w systemie ${ }^{4}$. Wspólny katalog był ogólnopaństwową bazą informacji bibliograficznej, która powstała w wyniku skoordynowanego i ujednoliconego opracowania zbiorów bibliotecznych.

Stowarzyszenie Jugosłowiańskich Bibliotek Narodowych w 1987 r. zaakceptowało system wspólnego opracowania zbiorów jako podstawę systemu biblioteczno-informacyjnego oraz systemu informacji naukowych i technologicznych Jugo-

\footnotetext{
2 E. Verona, Pravilnik i priručnik za izradbu abecednih kataloga, Zagreb 1986, s. 7.

${ }^{3}$ M. Bošeski, Bibliotečno rabotenje vo narodnite biblioteki, Skopje 1991, s. 37.

${ }^{4}$ M. Bošeski, Katalogizacija i sistematizacija na bibliotečen materijal, Skopje 2001, s. 5.
} 
sławii, a odpowiedzialność za rozwiązania organizacyjne i programowe przejął na siebie Instytut Nauk Informacyjnych (Institut informacijskih znanosti) z Mariboru (IZUM). Utworzona sieć komputerowa miała na celu racjonalizację pracy bibliotecznej w republikach ówczesnej Socjalistycznej Federacyjnej Republiki Jugosławii (SFRJ), budowę wspólnej i lokalnych baz informacji bibliograficznych, a także ich sprawne przeszukiwanie. Realizacja utworzenia wspólnego jugosłowiańskiego katalogu rozpoczęła się w $1988 \mathrm{r}$. i trwała niecałe cztery lata.

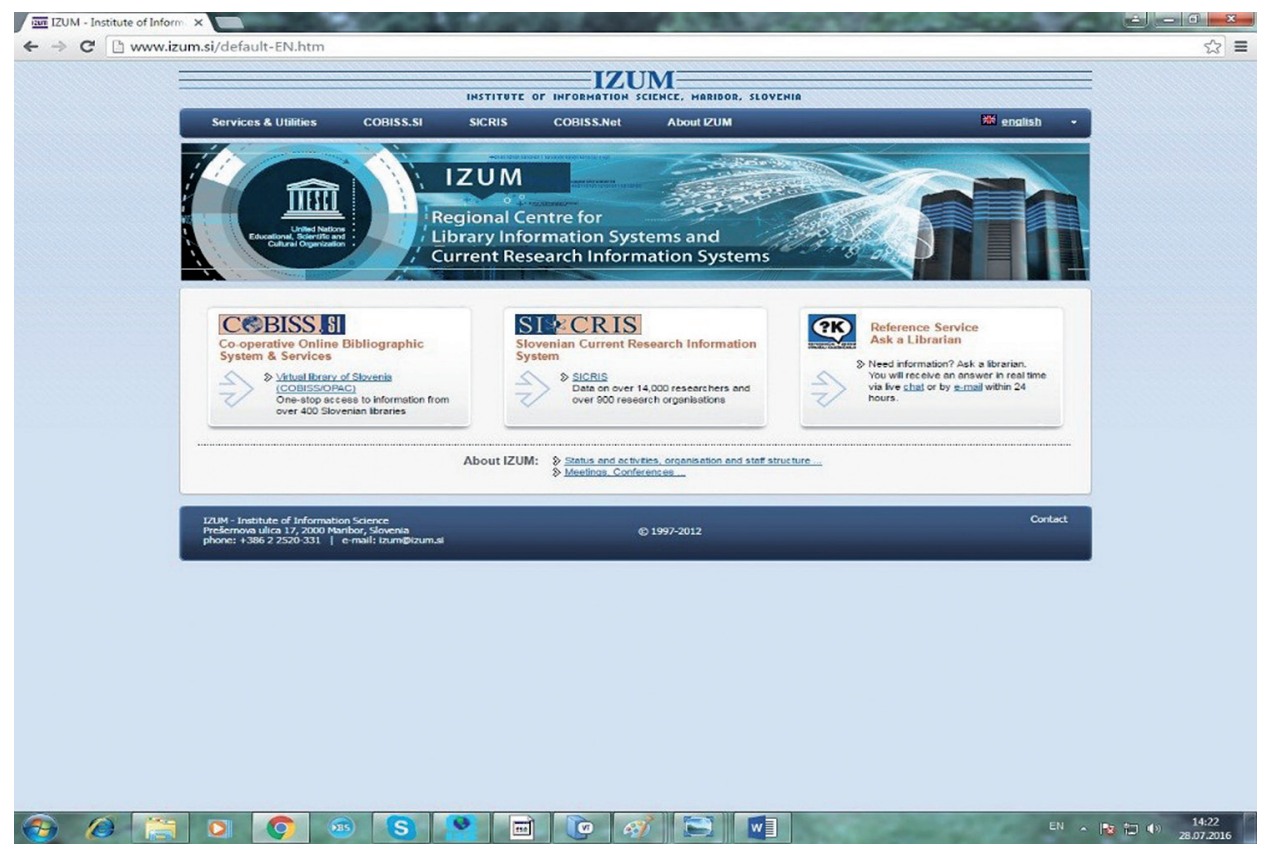

Rys. 1. Strona internetowa IZUM z Mariboru

Źródło: www.izum.si [dostęp: 28.07.2016].

W 1991 r. IZUM wypromował system COBISS ${ }^{5}$ (Kooperativni online bibliografski sistem in servisi) jako nadbudowę nad wcześniejszym systemem wspólnego opracowania zbiorów bibliotecznych. Implementacja COBISS stanowiła kontynuację projektu „System informacji naukowo-technologicznych Jugosławii” (SINTIJ), przy jego jednoczesnym unowocześnieniu. W COBISS funkcjonowało 55 bibliotek ze wszystkich ówczesnych republik SFRJ.

Wraz z rozpadem kraju rozpadł się cały system i przestała funkcjonować stworzona sieć biblioteczna. Biblioteki spoza Słowenii wystąpiły ze wspólnego systemu bibliotecznego i kontynuowały opracowywanie swoich zbiorów bibliotecznych na poziomie lokalnym ${ }^{6}$.

${ }^{5}$ COBISS.Net, http://www.cobiss.net/platforma_cobiss.htm [dostęp: 18.07.2016].

${ }^{6}$ Federacyjna Ludowa Republika Jugosławii, powstała w 1945 r., składała się z sześciu republik: Serbii, Chorwacji, Bośni i Hercegowiny, Czarnogóry, Słowenii i Macedonii, a także dwóch okręgów 
W miarę rozwoju nowo powstałych państw na terenie dawnej Jugosławii nastąpił powrót do istniejącej wcześniej współpracy między bibliotekami bałkańskimi. Po krótkim czasie niemal wszystkie biblioteki dawnego systemu odnowiły współpracę z IZUM i kontynuowały w swoich państwach budowę autonomicznego systemu biblioteczno-informacyjnego, opartego na programie COBISS. Poszczególne kraje zaczęły w swoich systemach bibliotecznych wykorzystywać najnowszą wtedy wersję programu - COBISS2. Stopniowo w każdym nowo powstałym kraju tworzono Centra Wirtualnych Bibliotek, koordynujące implementację programu COBISS w lokalnych bibliotekach.

Silna potrzeba współpracy i wymiany informacji bibliotecznej doprowadziła w 2003 r. do podpisania umowy o utworzeniu sieci COBISS.Net, dzięki której możliwy był swobodny przepływ rekordów bibliograficznych, tworzonych w autonomicznych systemach informacyjnych bibliotek Bośni i Hercegowiny, Czarnogóry, Macedonii, Słowenii i Serbii.

W 2006 r. do sieci COBISS.Net dołączyła Bułgaria. Nieco później, w 2013 r., przyłączyła się Albania. Biblioteki w Kosowie zaakceptowały propozycję włączenia ich do systemu COBISS, ale nie podjęto ostatecznych decyzji w sprawie implementacji COBISS w tym kraju. Obecnie na Półwyspie Bałkańskim w systemie COBISS funkcjonuje 750 bibliotek $^{7}$.

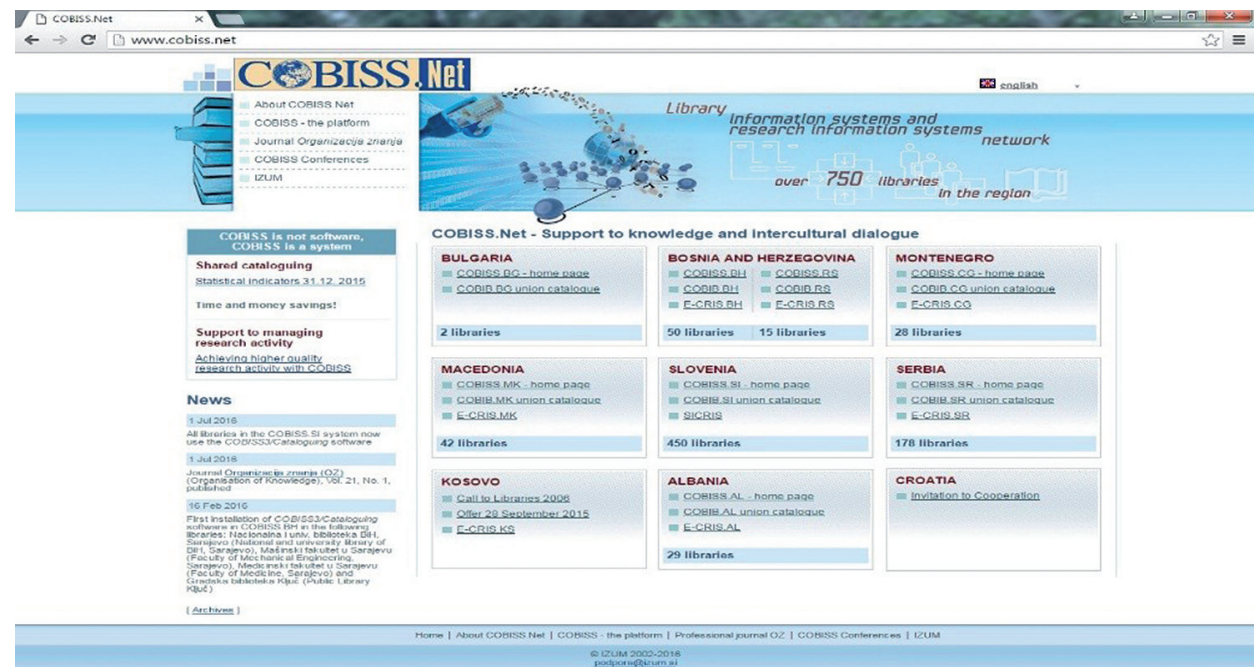

Rys. 2. Strona internetowa COBISS.Net

Źródło: www.cobiss.net [dostęp: 28.07.2016].

autonomicznych, należących do Republiki Serbii, Kosowa i Metohii oraz Wojwodiny. Wojna, która wybuchła na Bałkanach w 1991 r., doprowadziła do podziału Jugosławii i utworzenia siedmiu niezależnych państw. Zob. W. Felczak, T. Wasilewski, Historia Jugosławii, Wrocław 1985, s. 496.

${ }^{7}$ COBISS.Net. 


\section{Program COBISS}

Program COBISS jest oryginalnym produktem Instytutu Nauk Informacyjnych w Mariborze. Powstał w celu wspólnego katalogowania w różnych typach bibliotek: akademickich, uniwersyteckich, naukowych, publicznych, specjalnych i szkolnych. COBISS przedstawia z jednej strony model organizacyjny łączenia bibliotek w narodowy system biblioteczno-informacyjny, a z drugiej strony jest to program służący zautomatyzowaniu pracy bibliotecznej. Charakteryzuje go wspólne katalogowanie zbiorów, wspólna baza bibliograficzna COBIB (Baza bibliograficzna w systemie COBISS) i lokalne bazy informacji współpracujących bibliotek. COBISS3 jest trzecią generacją programu zautomatyzowania pracy bibliotecznej i dostępu do różnych baz informacyjnych, które rozwija i obsługuje IZUM ${ }^{8}$. Wykorzystywane są serwery $\mathrm{z}$ systemem operacyjnym Windows i serwery aplikacyjne $\mathrm{w}$ języku programowym Java. Użytkownicy korzystają z aplikacji na bazie języka programowego Java, dzięki czemu bibliotekarze mogą używać w swoich miejscach pracy komputerów z różnymi systemami operatywnymi (głównie Windows, ale również LINUX i MacOS). By uzyskać dobre efekty pracy w programie COBISS3, najlepiej używać nowych komputerów z dostępem do Internetu o prędkości minimum $256 \mathrm{~kb} / \mathrm{s}$. COBISS3 ma nowoczesny interfejs, oferuje możliwość wprowadzenia danych i przeszukiwania informacji także w cyrylicy, wykorzystuje standard UNICODE (ISO 10646) ${ }^{9}$. Pozwala na realizowanie różnych funkcji bibliotek narodowych i centrów COBISS, umożliwia wybór interfejsu użytkowego w kilku językach (słoweński, serbski, bośniacki, macedoński, bułgarski, albański i angielski).

Program COBISS wykorzystuje podstawy zasad katalogowania, zawarte w publikacji Zasady tworzenia katalogów alfabetycznych Ewy Werony (Pravilnik i priručnik za izradbu abecednih kataloga), które były stosowane przez biblioteki jugosłowiańskie. COBISS zawiera elementy Uniwersalnej Klasyfikacji Dziesiętnej, jak również zasady kreowania katalogów przedmiotowych, które są przystosowane do zasad katalogowania w każdym kraju wykorzystującym ten program. Język interfejsu programu COBISS, a także wszystkie elementy pomocnicze (help file) i różnorodne listy kodów przystosowane są do potrzeb językowych każdego kraju - użytkownika programu. COBISS umożliwia przygotowanie wydruku w alfabecie łacińskim i cyrylicy, jak również sortowanie informacji według obu alfabetów. Oprócz centralnych, istnieją lokalne listy kodów i wydruków, co pozwala na zachowanie regionalnej specyfiki bibliotek. COBISS posiada bogatą dokumentację przeznaczoną dla użytkowników, która jest uzupełniana wraz z nadbudową programu. Podręczniki do pracy w programie COBISS dostarczane są do bibliotek w formie drukowanej, ale są dostępne również on-line.

IZUM opracował program obowiązkowej edukacji dla swoich użytkowników, który jest wykorzystywany we wszystkich krajach pracujących w systemie

\footnotetext{
${ }^{8}$ Osnovna navodila COBISS3: priročnik za uporabnike, Maribor 2001, s. 5.

${ }^{9}$ COBISS.Net.
} 
COBISS. Każdy użytkownik uzyskuje licencję do pracy w programie COBISS $\mathrm{i}$ jest zobowiązany do przestrzegania wszystkich reguł pracy w systemie.

IZUM wspiera rozwój centrów COBISS na Bałkanach, oferuje swoją pomoc finansową, techniczną i merytoryczną, umożliwia również bibliotekarzom studia podyplomowe z dziedziny bibliotekarstwa na uczelniach w Chorwacji i Słowenii.

Segment programu COBISS3/Katalogowanie, dotyczący wspólnego katalogowania, pozwala na racjonalny podział pracy i oszczędność czasu zużywanego na procedury opracowania zbiorów bibliotecznych i prowadzenia katalogów. Jednostka bibliograficzna jest opracowywana tylko raz, następnie każdy rekord za pośrednictwem wspólnej bazy bibliograficznej COBIB jest udostępniany wszystkim uczestnikom systemu i sieci COBISS.Net. Wspólne katalogowanie charakteryzuje ścisłe powiązanie lokalnych baz informacji katalogowej poszczególnych bibliotek ze wspólną bazą danych.

Od momentu powstania sieci COBISS.Net i swobodnego przepływu rekordów bibliograficznych pomiędzy bibliotekami do chwili obecnej doszło do wymiany ponad 0,5 miliona rekordów bibliograficznych. Pod koniec 2013 r. w siedmiu wspólnych bazach danych COBIB istniało 10 milionów rekordów bibliograficznych, a w lokalnych bazach danych w ponad 700 bibliotekach bałkańskich zarejestrowano 23 miliony rekordów. W 2015 r. w bibliotekach utworzono jedynie $25 \%$ nowych rekordów, a przejętych zostało ze wspólnego katalogu 75\% rekordów, co pokazuje, jak dużo czasu i pieniędzy można zaoszczędzić dzięki funkcjonowaniu wspólnej sieci ${ }^{10}$. COBISS.Net umożliwia wszechstronną współpracę między bibliotekami regionu, porozumienie i dialog ponad granicami.

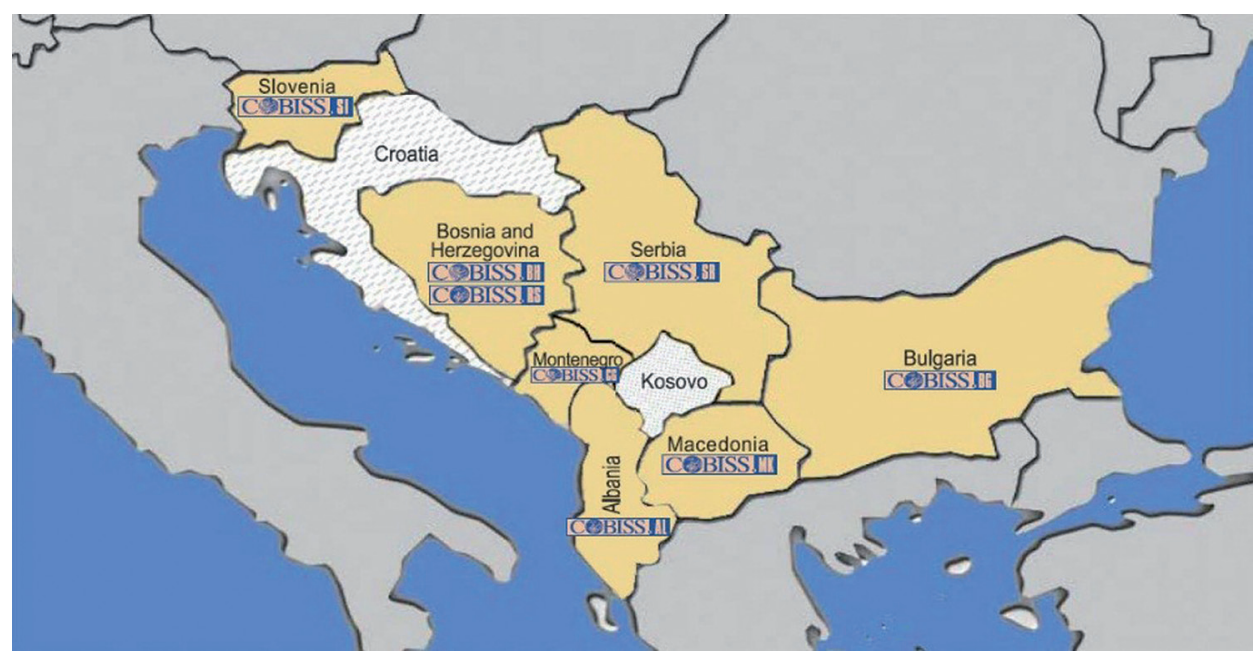

Rys. 3. Sieć COBISS.Net w krajach bałkańskich

Źródło: „Organizacija znanja” 2014, nr 2 (19), s. 65.

${ }^{10}$ Ibidem. 
Wspólna baza informacji COBIB i wszystkie lokalne bazy informacji bibliotek korzystających z systemu COBISS mają jednakową strukturę zapisów bibliograficznych i wszystkich informacji dotyczących zbiorów bibliotecznych.

Dostęp do baz informacji bibliograficznej w systemie COBISS - baz COBIB i lokalnych baz informacyjnych bibliotek - umożliwia aplikacja COBISS/ OPAC (Online Public Access Catalog) ${ }^{11}$. Pozwala ona na dostęp także do innych baz informacji COBISS: COLIB — baza informacji o bibliotekach, CORES baza wydawnictw ciągłych, CONOR — baza kartotekowa, wspólna dla bibliotek współpracujących w danym kraju, E-Cris - baza pracowników naukowych i instytucji naukowo-badawczych, EIINKS — dostęp do e-publikacji, LC NAMES baza kartotekowa Biblioteki Kongresu (Library of Congress, Washington) $\mathrm{i}$ inne.

Jeśli biblioteka pracująca w systemie COBISS posiada do obsługi czytelników program COBISS/Wypożyczanie, wówczas aplikacja COBISS/OPAC zapewnia on-line informacje o dostępności pojedynczego egzemplarza (Dostępny, Wypożyczony, Przewidywany zwrot). Użytkownicy mogą zarówno przedłużyć okres wypożyczenia, rezerwować książkę lub zamówić ją przez międzybiblioteczne wypożyczanie, jak i uzyskiwać wszystkie powiadomienia przez Internet.

Użytkownicy mogą korzystać również ze zmodyfikowanej wersji COBISS/ OPAC na telefony komórkowe - mCOBISS, która umożliwia dostęp do katalogu, rezerwację książek, uzyskanie informacji na temat biblioteki i inne.

Do wymiany informacji w systemie COBISS używany jest format COMARC/B - dla rekordów bibliograficznych i format COMARC/A — dla rekordów kartotekowych, które są budowane na formacie UNIMARC. Do wymiany międzynarodowej używany jest format MARC 21. Możliwa jest konwersja z formatu COMARC w format MARC 21 i odwrotnie ${ }^{12}$.

$\mathrm{W}$ procesie wspólnego opracowywania zbiorów w programie COBISS informacje są wprowadzane w bazach lokalnych, a jednocześnie uzupełniane we wspólnej bazie informacji COBIB. Bibliotekarz, który przystępuje do opracowania rekordu w bazie lokalnej, najpierw sprawdza, czy zapis bibliograficzny już istnieje we wspólnej bazie informacyjnej COBIB. Jeśli tak, przenosi go do swojej lokalnej bazy i uzupełnia o informacje dodatkowe. Jeśli natomiast rekordu nie ma we wspólnej bazie COBIB, bibliotekarz może go przejąć z sieci COBISS.Net lub innej bazy, do której ma dostęp, lub może tworzyć nowy rekord, który tym samym zostanie przeniesiony do wspólnej bazy informacyjnej. Możliwe jest również przejmowanie rekordów bibliograficznych z WorldCat i z katalogu Biblioteki Kongresu, jeśli narodowe COBISS-Centrum ma zawarte odpowiednie umowy. Wspólny katalog funkcjonujący w programie COBISS umożliwia opracowywanie każdego rekordu bibliograficznego tylko raz i tylko w jednym miejscu, co bardzo racjonalizuje pracę bibliotekarzy pracujących w systemie.

\footnotetext{
${ }^{11}$ COBISS/OPAC: priročnik za uporabnike, Maribor 2002, s. 5.

12 COBICC.Net.
} 
W każdym kraju korzystającym z programu COBISS utworzone zostały centra odpowiedzialne za automatyzację bibliotek. COBISS-Centrum, tworząc Wirtualną Bibliotekę, ma za zadanie planowanie i koordynację włączania bibliotek do wspólnego systemu komputerowego, zapewnienie właściwego oprogramowania i odpowiedniej dokumentacji do pracy bibliotek lokalnych w systemie, zarządzanie wspólną bazą danych COBIB i systemem COBISS, udzielanie fachowej pomocy przy zakupie, instalacji i konserwacji sprzętu komputerowego bibliotek, a także pomoc przy konwersji i przenoszeniu danych z innych systemów.

Na bieżąco sprawdzany jest poziom i ujednolicenie baz lokalnych i wspólnych baz informacyjnych COBIB. Prowadzone są systematyczne szkolenia bibliotekarzy, współtworzących bazy informacyjne. Po ukończeniu kursów szkoleniowych poświęconych pracy w formatach COMARC/B, COMARC/A i COMARC/H bibliotekarze otrzymują odpowiednie licencje zezwalające na pracę w systemie COBISS.

Od wielu lat w Mariborze organizowane są konferencje COBISS ${ }^{13}$, w których uczestniczą przedstawiciele bibliotek krajów włączonych do programu COBISS, a także goście z innych krajów europejskich. Bibliotekarze, informatycy, przedstawiciele różnych firm i instytucji państwowych, wspierających rozwój bibliotekarstwa, omawiają w trakcie konferencji różnorodne aspekty implementacji programu COBISS, perspektywy rozwoju bibliotekarstwa, możliwości wsparcia finansowego projektów bibliotecznych przez Unię Europejską, a także wpływ bibliotek na rozwój regionu Europy Południowo-Wschodniej.

\section{Komputeryzacja bibliotek macedońskich}

Pierwszą próbą automatyzacji procesów bibliotecznych w Republice Macedonii było przygotowanie w 1977 r. programu opracowania czasopism zagranicznych przez Wydział Nauk Przyrodniczych i Matematyki na Uniwersytecie im. św. Cyryla i Metodego przy współpracy Biblioteki Uniwersyteckiej im. św. Klimenta Ochrydzkiego w Skopje. W 1987 r. opracowany został program MAREBA (Makedonske Referalne Baze) na potrzeby Biblioteki Uniwersyteckiej. Spełniał on międzynarodowe standardy opracowania informacji bibliograficznych, lecz był dostępny tylko na poziomie lokalnym, bez możliwości dostępu on-line.

Rok później rozpoczęto zautomatyzowane opracowanie zbiorów bibliotecznych w Macedonii w ramach Projektu SNTIJ/BIS. Udział w tym przedsięwzięciu wzięły cztery instytucje: Biblioteka Uniwersytecka w Skopje, Biblioteka Uniwersytecka im. św. Klimenta Ochrydzkiego w Bitoli, Wydział Nauk Przyrodniczych i Matematyki na Uniwersytecie w Skopje i Kinoteka Macedonii. Instytucje te zostały wyposażone w odpowiedni sprzęt komputerowy, na którym do opracowania zbiorów bibliotecznych zainstalowano oprogramowanie COBISS, przygotowane

${ }^{13}$ Institut informacijskih znanosti IZUM, http://www.home.izum.si/cobiss/konference [dostęp: 18.07.2016]. 
przez IZUM z Mariboru ${ }^{14}$. Bibliotekę Uniwersytecką w Skopje wybrano wówczas na koordynatora, został tam umieszczony serwer i siedem stacji roboczych, a w pozostałych bibliotekach zainstalowano po jednej stacji roboczej. Komunikacja odbywała się za pomocą zakupionej linii telefonicznej i modułu.

Niestety wraz z rozpadem SFRJ w 1991 r. rozpadł się również ten system biblioteczny, i tylko niektóre $\mathrm{z}$ wymienionych instytucji kontynuowały pracę w oprogramowaniu COBISS na poziomie lokalnym.

W latach 1992-1996 macedońskie Ministerstwo Nauki sfinansowało projekt rozbudowy oprogramowania i wymiany sprzętu komputerowego. Rozpoczął się rozwój Macedońskiej Akademickiej Sieci Naukowo-Badawczej MARNET (Makedonska akademska naučno-istrazuvačka mreža). Opracowano projekty budowy Systemu Informacji Naukowych i Technologicznych, a także Systemu Informacji Biblioteczno-Dokumentacyjnej (SINTIM/BIS). Ponieważ realizacja tego projektu była ciągle odkładana, niektóre instytucje realizowały swoje plany, kupując oprogramowanie rodzime lub zagraniczne, które zaspokajało ich potrzeby i spełniało standardy pracy bibliotecznej.

W 1996 r. Biblioteki Uniwersyteckie w Skopje i Bitoli oraz Wydział Nauk Przyrodniczych i Matematyki Uniwersytetu w Skopje odnowiły umowę z IZUM i zainstalowały nową wersję oprogramowania COBISS, ale do 2002 r. pracowały niezależnie, budując jedynie lokalne bazy danych. Macedońska Akademia Nauk (MANU) w 2002 r. podjęła decyzję o wykorzystaniu oprogramowania COBISS w pracy swojej biblioteki. W tym też roku zaczęła funkcjonować wspólna baza danych COBIB.MK, która na starcie liczyła 248077 rekordów bibliograficznych. W 2003 r. do systemu przyłączyły się jeszcze trzy biblioteki: biblioteki publiczne w Sztip i Strumicy oraz Biblioteka Miejska im. Braka Miladinovci w Skopje.

System biblioteczny oparty na programie COBISS zaspokajał ówczesne potrzeby bibliotek macedońskich. W 2003 r. Biblioteka Uniwersytecka w Bitoli jako pierwsza biblioteka w Macedonii — wprowadziła zautomatyzowane udostępnianie zbiorów bibliotecznych. Rok później Ministerstwo Kultury Republiki Macedonii zaakceptowało realizację pierwszej fazy projektów automatyzacji 12 bibliotek publicznych wschodniego i zachodniego rejonu Macedonii. Projekty te obejmowały zakup komputerów, zainstalowanie oprogramowania COBISS i szkolenie bibliotekarzy.

Wsparcie ze strony Ministerstwa Kultury dla utworzenia systemu biblioteczno-informacyjnego, wykorzystującego program COBISS w bibliotekach i innych instytucjach, było kluczowym czynnikiem podpisania w grudniu 2004 r. umowy o zorganizowaniu narodowego biblioteczno-informacyjnego systemu w Republice Macedonii i zautomatyzowaniu bibliotek. W Bibliotece Uniwersyteckiej w Skopje utworzono centrum - Wirtualną Bibliotekę Macedonii (VBM) jako serwis biblioteczno-informacyjny systemu COBISS.MK. Tym samym w Bibliotece Unis. 237.

14 Ž. Gjalevska, Avtomatizacija knjižnic v Makedoniji, „Organizacija znanja” 2005, nr 4 (21), 
wersyteckiej podjęto działania unowocześnienia bazy komputerowej i udoskonalenia oprogramowania, a także utworzono i wyposażono Centrum Edukacji, niezbędne do prowadzenia szkoleń bibliotekarzy w oprogramowaniu COBISS. W tym samym roku zaczęła też funkcjonować sieć COBISS.Net, dzięki której biblioteki w Macedonii, pracujące z oprogramowaniem COBISS, miały dostęp do wspólnego katalogu systemu COBISS oraz możliwość przejmowania rekordów bibliotecznych do swoich baz lokalnych. Rozumiejąc znaczenie tego projektu, ówczesny dyrektor Biblioteki Narodowej i Uniwersyteckiej w Skopje, Borko Zafirovski, w imieniu bibliotek Republiki Macedonii w 2003 r. podpisał Umowe o instalacji sieci COBISS.NET pomiędzy systemami COBISS w Słowenii, Macedonii, Serbii i Czarnogóry, a także Bośni i Hercegowiny ${ }^{15}$.

W Republice Macedonii działa ponad 200 różnych bibliotek. W systemie COBISS.MK funkcjonuje tylko część z nich. Trwają intensywne prace nad włączeniem pozostałych placówek do programu COBISS, lecz problemy natury finansowej, technicznej i niedobór wyszkolonych kadr bibliotekarzy spowalniają ten proces.

W bazie COBISS.MK w 2015 r. funkcjonowały 42 biblioteki, w tym Biblioteka Narodowa, 8 bibliotek uniwersyteckich i wydziałowych, 26 bibliotek publicznych i 7 bibliotek specjalnych. Liczba rekordów bibliotecznych we wspólnej bazie danych COBISS.MK w 2015 r. wynosiła 571 576, a w lokalnych bazach bibliotek $-965345^{16}$.

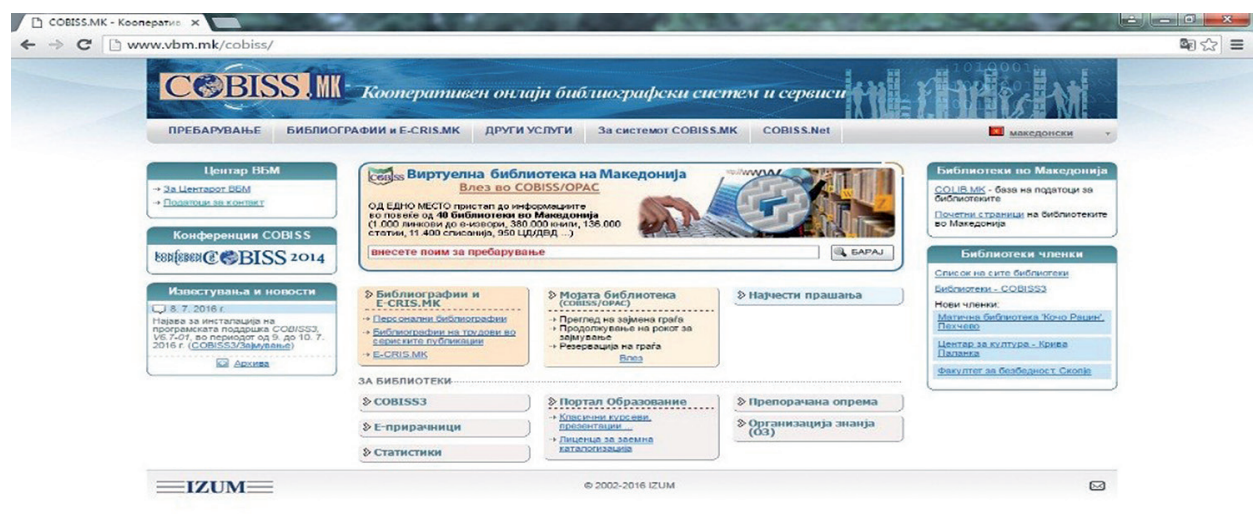

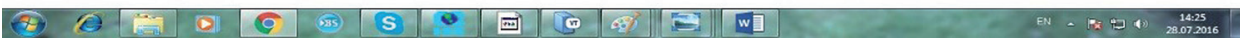

Rys. 4. Strona internetowa COBISS.MK

Źródło: www.vbm.mk/cobiss/ [dostęp: 22.08.2016].

15 Ibidem.

16 COBISS.MK, http://www.vbm.mk/cobiss [dostęp: 18.07.2016]. 
Zwiększone zapotrzebowanie oraz duże zainteresowanie w Macedonii dostępem i korzystaniem ze zdigitalizowanych dokumentów, baz i banków danych zaowocowało utworzeniem konsorcjum MeB (Makedonski elektronski bazi) przy współpracy Fundacji eIFL. W skład tego konsorcjum weszły biblioteki uniwersyteckie, publiczne, miejskie i specjalne. MeB przez swoje strony internetowe umożliwia dostęp do baz EBSCO, dostęp do dużej liczby e-źródeł, e-czasopism i e-książek w wolnym dostępie. Projekty dotyczące digitalizacji różnorodnych zbiorów bibliotecznych w Macedonii zaowocowały intensywnymi pracami w tym kierunku i stworzeniem macedońskiej bazy zdigitalizowanych materiałów bibliotecznych DLIB ${ }^{17}$.

\section{Proces automatyzacji bibliotek w Serbii}

Pierwsza próba zastosowania komputerów w bibliotekach Republiki Serbii była związana z wprowadzeniem w życie w 1985 r. projektu zautomatyzowanego przetwarzania danych w Bibliotece Narodowej, realizowanego przez Instytut „Mihajlo Pupin” w Belgradzie. System ten został zainstalowany w lokalnej sieci terminali, z serwerem TIM 200, UNIX i terminalami tej samej marki, wyprodukowanymi w Instytucie „Mihajlo Pupin”.

Kluczowym momentem zautomatyzowania pracy w bibliotekach Republiki Serbii okazał się rok 1988, kiedy to dwie znaczące biblioteki - Biblioteka Narodowa Serbii w Belgradzie i Biblioteka „Matice Srpske” w Nowym Sadzie oraz inne większe biblioteki SFRJ zapoczątkowały wdrażanie projektu System Informacji Naukowo-Technicznej Jugosławii. Zakładał on połączenie w jedną sieć większości bibliotek ówczesnej Jugosławii. System ten był zaplanowany jako Wide Area Computer Network ze wspólnym katalogiem, który łączył informacje o zbiorach wszystkich bibliotek objętych systemem. Centralna baza, z rekordami bibliograficznymi wszystkich bibliotek w sieci, została umieszczona w IZUM w Mariborze, a lokalne serwery w Serbii były zainstalowane w głównych bibliotekach Belgradu i Prisztiny ${ }^{18}$. Główne serwery i różne modele małych serwerów VAX były ze sobą powiązane przez JUPAK - sieć publiczną do transferu danych. Sieć lokalną w większych bibliotekach na początku oparto na terminalach, a dopiero po 1995 r. zbudowano lokalną sieć komputerową.

Po zakończeniu przygotowań i zakupie serwerów Biblioteka Narodowa Serbii i Biblioteka „Matice Srpske” w 1989 r. rozpoczęły tworzenie lokalnej elektronicznej bazy danych w ramach jugosłowiańskiego systemu wspólnego opracowania zbiorów. Oprogramowanie tego systemu zostało oparte na pakiecie katalogowania programu ATLASS, opracowanego przez IZUM. Była to wcześniejsza wersja progra-

17 dlib.mk, http://www.dlib.mk [dostęp: 18.07.2016].

18 V. Stevanović, Avtomatizacija knjižnic v Srbiji, „Organizacija znanja” 2005, nr 4 (10), s. 215. 
mu COBISS. W 1992 r. IZUM zainstalował na serwerze Biblioteki Narodowej Serbii wspólny jugosłowiański katalog, z którego można było korzystać poprzez OPAC.

System ten funkcjonował do momentu wybuchu wojny na Bałkanach. Wszystkie większe biblioteki w Serbii, które do tej pory uczestniczyły w budowie dawnego ujednoliconego systemu informacji bibliotecznej, ograniczyły współpracę i w latach 1992-2001 kontynuowały opracowywanie zbiorów na poziomie lokalnym. Zetknięto się wówczas z wieloma problemami, które powstały z jednej strony z powodu szybkiego rozwoju współczesnych technologii i społeczeństw informacyjnych, a z drugiej — z powodu rezultatów regresji w okresie dziesięcioletniego niedemokratycznego reżimu w Serbii, wojny i sankcji ze strony wspólnoty międzynarodowej.

W 1992 r. Ministerstwo Nauki Republiki Serbii sfinansowało utworzenie serbskiego programu katalogowania BISIS. Po dwóch latach finansowanie zostało przerwane, a ekipa Wydziału Nauk Przyrodniczych i Matematyki Uniwersytetu w Nowym Sadzie utworzona do realizacji projektu zaczęła rozwijać własny pakiet oprogramowania. Paralelnie rozwijał się też program biblioteczny BIBLIO na bazie programu ISIS UNESCO, na podstawie systemu operacyjnego DOS i z możliwością powiązania z siecią NOVELL. Program ten funkcjonował jako tymczasowe rozwiązanie wypełniające lukę w systemie wspólnego opracowania zbiorów bibliotecznych. Około roku 2000 pojawiła się wersja Windows tego programu. Oprócz programu BIBLIO pojawiły się różne nowe programy używane w bibliotekach serbskich. Jednak większość programów nie była dostatecznie dopracowana i nie zaspokajała oczekiwań ówczesnych bibliotekarzy.

W 1998 r. Biblioteka „Matice Srpske” i Biblioteka YUBIN (Jugosłowiański Bibliograficzny Instytut Informacyjny), a w roku 2001 Biblioteka Narodowa Serbii i Biblioteka Uniwersytecka im. Svetozara Markovica w Belgradzie zrezygnowały ze starego programu COBISS na platformie VAX, podjęły na nowo współpracę z IZUM i zainstalowały nową wersję oprogramowania COBISS z serwerami ALPHA. Była to początkowa faza tworzenia wspólnego katalogu poprzez połączenie na tym samym oprogramowaniu katalogów lokalnych tych czterech instytucji ${ }^{19}$.

W lutym 2003 r. wprowadzono system wspólnego katalogowania jako pierwszą fazę realizacji projektu „Wirtualna biblioteka Serbii”. Pracownicy IZUM zainstalowali katalog i moduł oprogramowania do opracowywania zbiorów. Wspomniany katalog zbiorów powstał w wyniku połączenia elektronicznych katalogów baz danych Biblioteki „Matice Srpske” (750 tys. rekordów bibliograficznych), Narodowej Biblioteki Serbii (430 tys. rekordów), Biblioteki Uniwersyteckiej (98 tys. rekordów) i Biblioteki YUBIN (39 tys. rekordów). Wspólny serbski katalog na stracie liczyłł 1300000 rekordów bibliotecznych. W 2005 r. serbski katalog baz danych COBIB.SR posiadał już 1565000 rekordów, a w systemie działały 43 biblioteki. Po dziesięciu latach rozwoju systemu COBISS.SR, w 2015 r., w jego

19 Ibidem, s. 216. 
składzie funkcjonowało 171 bibliotek, w tym 70 bibliotek narodowych, uniwersyteckich i wydziałowych, 77 bibliotek publicznych i 24 biblioteki specjalne. Obecnie w systemie COBISS pracuje 178 bibliotek serbskich. Liczba rekordów bibliograficznych we wspólnej bazie danych COBIB.SR w 2015 r. wynosiła 2912 595, a liczba rekordów w lokalnych bazach danych $-6335241^{20}$.

Szybki rozwój systemu COBISS w Serbii możliwy był dzięki wsparciu rządu, a także różnorodnym dotacjom. Fundacja Open Society pomogła przy realizacji pierwszej fazy projektu Wirtualna Biblioteka Serbii poprzez jego sfinansowanie, zakup potrzebnego sprzętu, opłacenie szkoleń dla bibliotekarzy. Donacja programu TEMPUS Unii Europejskiej pomogła przy zakupie sprzętu komputerowego, niezbędnego do podłączenia zarówno do systemu bibliotek uniwersyteckich w Belgradzie, Niszu, Kragujevac, jak i dużej liczby bibliotek wydziałowych różnych uczelni serbskich. IZUM pomógł w szkoleniu informatyków i bibliotekarzy serbskich w swojej siedzibie w Mariborze oraz udzielił pomocy przy zakupie sprzętu komputerowego, niezbędnego do szybszego rozwoju systemu wspólnego katalogowania w Serbii w programie COBISS.

\section{Komputeryzacja bibliotek Bośni i Hercegowiny}

Początki tworzenia ujednoliconego systemu informatycznego w Republice Bośni i Hercegowiny przypadają na rok 1989. Rozpoczęto wówczas implementację systemu COBISS przez włączenie do systemu wspólnego katalogowania Biblioteki Narodowej Bośni i Hercegowiny, Narodowej Biblioteki w Tuzli, Narodowej Biblioteki w Mostarze, Narodowej Biblioteki „Petar Kocié” w Banja Luce i Biblioteki Instytutu Nefrologii przy Centrum Klinicznym w Sarajewie. W latach 1989-1992 utworzono ponad 20 tys. rekordów bibliotecznych ${ }^{21}$.

Niestety dynamiczny rozwój wspólnego systemu bibliotek bośniackich został przerwany na początku lat 90 . ubiegłego stulecia, kiedy doszło do rozpadu SFRJ. Działania wojenne, podział Bośni i Hercegowiny na kantony, trudne początki współpracy między instytucjami podzielonego kraju nie ułatwiały rozwoju bośniackim bibliotekom.

W 1996 r. wznowiono współpracę bibliotek Bośni i Hercegowiny z IZUM. Po dwóch latach został zrealizowany projekt komputerowego powiązania bibliotek bośniackich przez Internet. Projekt ten zaakceptowały wszystkie Uniwersytety — w Banja Luce, Mostarze, Sarajewie i Tuzli — a także liczne biblioteki z całej Bośni. Realizację ujednoliconego systemu biblioteczno-informacyjnego (w okresie 1998-2000) sfinansował w największym stopniu rząd Słowenii. Wówczas po-

${ }^{20}$ COBISS.SR, http://www.vbs.rs/cobiss [dostęp: 18.07.2016].

${ }^{21}$ N. Hajdarović, Avtomatizacija in knjižnic v BIH, „Organizacija znanja” 2005, nr 4 (10), s. 243. 
między uniwersytetami Bośni i Hercegowiny a IZUM została podpisana umowa o utworzeniu COBISS Centrum. Niestety w 2004 r. COBISS Centrum w Bośni przestało istnieć z powodu braku regulacji sposobów jego finansowania.

Wspólna baza danych COBIB.BH na początku swojego funkcjonowania liczyła ponad 167 tys. rekordów bibliotecznych, a kryterium wyboru kreowanych rekordów była różnorodność językowa zbiorów (zbiory w językach bośniackim, chorwackim lub serbskim) ${ }^{22}$.

W 2005 r. między Biblioteką Narodową i Uniwersytecką Bośni i Hercegowiny a IZUM podpisana została umowa o współpracy i implementacji systemu COBISS. Od tego roku COBISS.BH zaczął funkcjonować na nowo, a 12 bibliotek podpisało z Wirtualną Biblioteką BIH umowę o pełnym członkostwie ${ }^{23}$. Niestety część bibliotek, które przed wojną były włączone do systemu, nie zdołało po zakończeniu działań wojennych włączyć się na nowo do programu COBISS. Każda przerwa w działalności bibliotek i funkcjonowaniu w systemie była trudna do nadrobienia. Znaczącej pomocy udzieliły bibliotekom bośniackim takie organizacje, jak: UNESCO, World Bank, Open Society USAID, Instytut Goethego oraz rządy Austrii, Turcji, Słowenii, Egiptu, Chorwacji i inne.

W bazie COBISS.BH w 2015 r. funkcjonowało 50 bibliotek, w tym 29 bibliotek narodowych, uniwersyteckich i wydziałowych, 17 bibliotek publicznych i 4 biblioteki specjalne. Liczba rekordów bibliotecznych w 2015 r. wynosiła 420461 we wspólnej bazie danych COBISS.BH i $548070 \mathrm{w}$ lokalnych bazach bibliotek ${ }^{24}$.

W 2013 r. wspólna baza COBISS.BH została podzielona i powstała na terenie Bośni i Hercegowiny nowa baza Serbskiej Republiki - COBISS.RS. Baza ta w 2015 r. obejmowała 15 bibliotek, wśród których 7 to biblioteki narodowe, uniwersyteckie i wydziałowe, 7 bibliotek publicznych i 1 biblioteka specjalna. Liczba rekordów bibliotecznych we wspólnej bazie danych COBISS.RS w 2015 r. wynosiła 100 950, natomiast w lokalnych bazach bibliotek Republiki Serbskiej - 115270 rekordów ${ }^{25}$.

\section{Automatyzacja bibliotek w Czarnogórze}

Od końca lat 80. XX stulecia do roku 1992 biblioteki Czarnogóry, republiki będącej częścią SFR Jugosławii, wchodziły w skład sieci bibliotecznej BISJU. Utworzono ją jako element Systemu Informacji Naukowych i Technologicznych Jugosławii, zapoczątkowanego przez Związkowy Komitet Nauki, Technologii i Informatyki. System biblioteczno-informacyjny był zaplanowany jako sieć kom-

\footnotetext{
22 Ibidem, s. 244.

23 COBISS.Net.

${ }^{24}$ Ibidem.

${ }^{25}$ COBISS.RS.
} 
puterowa, w ramach której funkcjonował wspólny katalog z danymi na temat zbiorów bibliotecznych wszystkich bibliotek włączonych do systemu. Centralna baza znajdowała się w IZUM w Mariborze, a lokalne centrum dla Czarnogóry zostało zorganizowane w Bibliotece Uniwersyteckiej w Podgoricy (dawny Titograd). Podłączone były do niego bazy Biblioteki Uniwersyteckiej, baza Centralnej Biblioteki Narodowej Czarnogóry im. Djurdje Crnojevića w Cetinje, bazy Biblioteki Instytutu Aluminium w Podgoricy i Biblioteki Instytutu Metalurgii w Nikšiću ${ }^{26}$.

Po rozpadzie Jugosławii tylko dwie biblioteki - Centralna Biblioteka Narodowa w Cetinje, pełniąca funkcję biblioteki narodowej w Czarnogórze, i Biblioteka Uniwersytecka w Podgoricy — kontynuowały pracę w oprogramowaniu COBISS. Funkcjonująca wówczas sieć publiczna do transferu danych - JUPAK, a także zła jakość techniczna sieci komputerowej bibliotek nie uniemożliwiały rozwój całego systemu bibliotecznego. Pilna potrzeba zautomatyzowania pracy bibliotecznej zmobilizowała część bibliotek do zakupienia oprogramowania opartego na CDS/ISIS i systemie operacyjnym DOS, by za ich pomocą tworzyć własne off-line katalogi zbiorów. Większość bibliotek korzystała z programu BIBLIO, do którego nie było dostępu przez Internet.

Dzięki inicjatywie Centralnej Biblioteki Narodowej i dużemu zainteresowaniu bibliotek Czarnogóry w 1999 r. wznowiona została współpraca pomiędzy Centralną Biblioteką Narodową w Cetinje i Biblioteką Uniwersytecką w Podgoricy a IZUM. Współpracę tę poparło Towarzystwo Bibliotekarzy Czarnogóry, uznając, że dla rozwoju systemu biblioteczno-informacyjnego kraju najlepszym rozwiązaniem jest implementacja systemu COBISS i realizacja projektu Wirtualnej Biblioteki Czarnogóry. Do jego realizacji niezbędne było stworzenie zarówno nowoczesnej sieci komputerowej, jak i zakup odpowiedniego sprzętu.

Ostateczna umowa o przystąpieniu Czarnogóry do systemu COBISS została podpisana w 2001 r. Projekt utworzenia Wirtualnej Biblioteki Czarnogóry przewidywał połączenie bibliotek Czarnogóry w ujednolicony system informacyjny, który umożliwiałby użytkownikom bibliotek dostęp do bibliotecznej elektronicznej bazy danych w kraju i w sieci COBISS.Net. W obu bibliotekach zainstalowane zostały serwery i inny sprzęt potrzebny do funkcjonowania wspólnej bazy i lokalnych baz danych oraz różnorodny sprzęt niezbędny do sprawnego funkcjonowania systemu COBISS w bibliotekach Czarnogóry. Środki finansowe potrzebne do wyposażenia obu bibliotek w sprzęt komputerowy pochodziły w większości z donacji IZUM z Mariboru i z Fundacji Open Society z Budapesztu ${ }^{27}$.

W bazie COBISS.CG w 2015 r. funkcjonowało 28 bibliotek, w tym 11 bibliotek narodowych, uniwersyteckich i wydziałowych, 12 bibliotek publicznych, 4 specjalne i 1 biblioteka szkolna. Liczba rekordów bibliotecznych w tym roku

26 J. Djurović, Stanje avtomatizacije knjižnic v Črni Gori, „Organizacija znanja” 2005, nr 4 (10), s. 230.

27 Ibidem, s. 232. 
wynosiła 393108 we wspólnej bazie danych COBISS.CG i 560263 w lokalnych bazach bibliotek kraju ${ }^{28}$.

Rozbudowanie sieci COBISS w Czarnogórze, tak jak w innych dawnych republikach jugosłowiańskich, pozwoliło na lepszą współpracę pomiędzy bibliotekami, szkołami, instytucjami naukowo-badawczymi, na integrację nauki i kultury, a także na oferowanie użytkownikom bibliotek i innym obywatelom usług najwyższej jakości. W ten sposób biblioteki Czarnogóry mogą spełniać funkcję, jaka jest im współcześnie przypisana.

\section{Biblioteki albańskie i COBISS}

Automatyzacja bibliotek Albanii i włączenie ich do sytemu COBISS odbywało się z dużymi utrudnieniami. Zauważalna była niechęć do udostępnienia informacji o zbiorach bibliotecznych, duży opór wobec wszelkich zmian, a także lęk przed postępem i współpracą z regionem i światem.

Po kilku latach nieudanych prób namawiania bibliotekarzy albańskich do przyłączenia się do bałkańskiej grupy państw włączonych do systemu COBISS w $2012 \mathrm{r}$. podpisano umowę między kilkoma bibliotekami albańskimi a IZUM. Od 2013 r. stopniowo coraz więcej bibliotek przyłączało się do systemu COBISS.AL. Niestety nadal nie działa w systemie COBISS Albańska Biblioteka Narodowa. Funkcję COBISS-Centrum dla bibliotek albańskich spełnia tymczasowo IZUM w Mariborze.

W 2015 r. w bazie COBISS.AL funkcjonowało już 29 bibliotek, w tym 18 bibliotek narodowych, uniwersyteckich i wydziałowych, 8 bibliotek publicznych i 3 biblioteki specjalne. Liczba rekordów bibliotecznych w 2015 r. wynosiła 89523 we wspólnej bazie danych COBISS.AL, a w lokalnych bazach bibliotek albańskich $-95129^{29}$.

Obecnie proces rozwijania systemu COBISS w Albanii postępuje dynamicznie. Albańskie biblioteki w szybkim tempie poszerzają sieć COBISS na swoim terenie, podjęły też wszechstronną współpracę z innymi bibliotekami bałkańskimi.

\section{Implementacja systemu COBISS w Bułgarii}

Pierwsze próby stworzenia w Bułgarii zautomatyzowanego systemu bibliotecznego przypadają na rok 1993. System ten nosił nazwę: Narodowa zautomatyzowana sieć informacji bibliotecznej (Nacionalna avtomatizirana informacijska knjižnična mreža). Jednak rząd Bułgarii nie był zainteresowany inwestowaniem w rozwój tego systemu. Każda biblioteka decydowała sama, jakiego oprogra-

${ }^{28}$ COBISS.CG, http://vbcg.vbcg.me/cobiss [dostęp: 18.07.2016].

${ }^{29}$ COBISS.AL, http://www.al.cobiss.net [dostęp: 18.07.2016]. 
mowania będzie używała przy opracowywaniu zbiorów i jak będzie przebiegała automatyzacja procesów bibliotecznych. $\mathrm{Z}$ tego powodu biblioteki bułgarskie korzystają z różnorodnego oprogramowania. Część bibliotek uniwersyteckich używa systemu Aleph, natomiast biblioteki publiczne wykorzystują oprogramowanie WINISIS lub rodzimy program AB-bibliotheca ${ }^{30}$. Biblioteka Narodowa im. św. Cyryla i Metodego w Sofii w 1993 r. stworzyła elektroniczny katalog zbiorów, oparty na oprogramowaniu WINISIS.

W 2006 r. zarówno IZUM, jak i przedstawiciele bibliotek krajów bałkańskich działających w sieci COBISS zwróciły się do pozostałych bibliotek regionu, by przeanalizowały swoje strategie rozwoju i przyłączyły do wspólnego projektu COBISS. Net. Na zaproszenie odpowiedziała Biblioteka Narodowa Bułgarii i podpisała porozumienie o swobodnym przepływie rekordów bibliograficznych, które są tworzone $\mathrm{w}$ autonomicznych biblioteczno-informacyjnych systemach w sieci COBISS.Net. Przygotowany został użytkowy interfejs strony COBISS.BG w języku bułgarskim, przetłumaczono na język bułgarski podręczniki do korzystania z różnych aplikacji programu COBISS i zapoczątkowano tworzenie wspólnego katalogu danych bibliotecznych w Bułgarii.

Biblioteka Narodowa im. św. Cyryla i Metodego pełni funkcję Narodowego Centrum COBISS w Bułgarii i jest tym samym ośrodkiem koordynującym implementację systemu COBISS w bibliotekach kraju.

W 2015 r. Biblioteka Narodowa Bułgarii wprowadziła do wspólnej bazy 9772 rekordy opisów bibliograficznych, zmodyfikowała 18208 opisów, wprowadziła 5468 rekordów kartotekowych i zmodyfikowała 30355 rekordów.

Implementacja COBISS w Bułgarii nie odbywa się tak dynamicznie, jak w innych krajach. W 2015 r. w bazie COBISS.BG funkcjonowały dwie biblioteki, $\mathrm{w}$ tym jedna biblioteka narodowa i jedna publiczna.

Liczba rekordów bibliotecznych w 2015 r. wynosiła 847454 we wspólnej bazie danych COBISS.BG, a w lokalnych bazach bibliotek — 986806 rekordów $^{31}$.

Na terenie Bułgarii od 2009 r. funkcjonuje Fundacja NABIS (Narodowy Akademicki Biblioteczno-Informacyjny System), w skład której wchodzą Centralna Biblioteka Bułgarskiej Akademii Nauk, Uniwersytet im. św. Klimenta Ochrydzkiego w Sofii, Uniwersytet Amerykański w Bułgarii. Projekt NABIS jest finansowany przez Fundację „Ameryka dla Bułgarii”. Fundacja NABIS wspiera rozwój bibliotek akademickich i innych dużych bibliotek bułgarskich. Wspólny katalog elektroniczny - NALIS (National Academic Library and Information System) tworzą zbiory ponad 40 bibliotek bułgarskich i zagranicznych ${ }^{32}$.

${ }^{30}$ M. Vasileva, Kratko poročilo o stanju avtomatizacije v Nacionalni knjižnici „Sv. Ciril in Metod”, Sofija, „Organizacija znanja” 2005, nr 4 (10), s. 246.

${ }^{31}$ COBISS.BG, http://www.bg.cobiss.net [dostęp: 18.07.2016].

32 NALIS Foundation, http://www.nalis.bg [dostęp: 18.07.2016]. 


\section{Programy biblioteczne w Chorwacji}

Biblioteki w Chorwacji w latach 80. XX w., podobnie jak biblioteki w innych republikach dawnej Jugosławii, rozwijały się w ramach systemu informacji naukowych i technologicznych SNTIJ (Sistem na naučno-tehnološki informacii na Jugoslavija). W 1980 r. Biblioteka Narodowa i Uniwersytecka w Zagrzebiu zaakceptowały format UNIMARC przy tworzeniu swojej bazy danych. Rok później format UNIMARC został przyjęty w bibliotekach całej Jugosławii. W tym formacie katalogowana była nowa literatura chorwacka (Croatica) we wszystkich bibliotekach Republiki Chorwacji. W 1982 r. UNIMARC został użyty przy opracowaniu artykułów z czasopism chorwackich, a rok później format UNIMARC zaczęto wykorzystywać do katalogowania jugosłowiańskiego egzemplarza depozytowego (Iugoslavica). W 1989 r. w Chorwacji został wydany podręcznik Priručnik za UNIMARC, który następnie zaakceptowano jako jugosłowiański standard.

Po 1991 r., gdy doszło do rozpadu SFRJ, a tym samym do rozpadu całego jugosłowiańskiego systemu bibliotecznego, biblioteki chorwackie nie włączyły się do systemu COBISS, tak jak zrobiły to wszystkie biblioteki w dawnych republikach Jugosławii.

Biblioteka Narodowa i Uniwersytecka w Zagrzebiu zamówiły przygotowanie na potrzeby bibliotek chorwackich nowego oprogramowania, spełniającego międzynarodowe standardy. W 1992 r. wszedł w użycie nowy system biblioteczny CROLIST. Program ten wykorzystywały do opracowania swoich zbiorów zarówno Biblioteka Narodowa i Uniwersytecka, jak i część bibliotek chorwackich. Kilka lat później, w 2006 r., Biblioteka Narodowa przestała korzystać z programu CROLIST i rozpoczęła implementację systemu Endeavor/Voyager, który opiera się na formacie MARC 21. Dwa lata później Biblioteka Narodowa zaplanowała przejście z programu Voyager na program Aleph, oparty na formatach MARC 21 i UNIMARC ${ }^{33}$. Obecnie na terenie całej Chorwacji biblioteki korzystają z różnych programów bibliotecznych: BibliosAMweb, Metel, Medved, Zaki i Crolist ${ }^{34}$.

Wielokrotnie były ponawiane rozmowy firmy IZUM i przedstawicieli wszystkich bałkańskich COBISS-Centrów z przedstawicielami bibliotek chorwackich na temat ich przyłączenia do systemu COBISS.Net. Wciąż jednak nie podjęto ostatecznej decyzji w sprawie ujednolicenia oprogramowania we wszystkich bibliotekach w Chorwacji i włączenia ich do wspólnego bałkańskiego katalogu zbiorów bibliotecznych.

${ }^{33}$ Nacionalna i Sveučilišna Knjižnica u Zagrebu, http://www.nsk.hr [dostęp: 18.07.2016].

${ }^{34}$ Knjižnica Filozofskog fakulteta Sveučilišta u Zagrebu, http://darhiv.ffzg.unizg.hr [dostęp: 18.07.2016]. 


\section{COBISS w Kosowie i Metohii}

Biblioteki okręgu autonomicznego Kosowo przed rozpadem SFR Jugosławii były częścią systemu informacji naukowych i technologicznych SNTIJ. Rozpad kraju, długotrwałe działania wojenne, powolne tworzenie nowych struktur państwowych w Kosowie, ogromne problemy finansowe i organizacyjne wpłynęły negatywnie na proces rozwoju bibliotekarstwa w Kosowie.

Na terenie Kosowa funkcjonuje obecnie kilka rodzajów bibliotek: Biblioteka Narodowa, Biblioteka Uniwersytecka w Prisztinie, biblioteki różnych instytucji, biblioteki publiczne, biblioteki szkolne i specjalne. Początki istnienia Biblioteki Narodowej sięgają roku 1944, kiedy to w Prizrenie została utworzona Biblioteka Regionalna, która w latach 1963-1970 funkcjonowała jako Biblioteka Okręgu Autonomicznego Kosowo.

W 1970 r. powstał Uniwersytet w Prisztinie i wówczas biblioteka uniwersytetu przejęła funkcję Biblioteki Narodowej i Uniwersyteckiej. W 2006 r. doszło do oddzielenia centralnej biblioteki uniwersytetu prisztińskiego i utworzenia Centrum Biblioteki Uniwersyteckiej (CUB). Rozwój bibliotek w Kosowie wspierany jest przez programy UNESCO $\mathrm{i}$ innych instytucji europejskich ${ }^{35}$.

Mimo dużego zainteresowania bibliotek z Kosowa programem COBISS i wielu prób przekonywania do przyłączenia ich do sieci COBISS.Net, biblioteki Kosowa nie znalazły się jeszcze na mapie wspólnej bałkańskiej sieci COBISS.

\section{Sieć COBISS w Słowenii}

Początki automatyzacji bibliotek słoweńskich sięgają lat 70. XX w. W $1973 \mathrm{r}$. odbyła się w Mariborze pierwsza jugosłowiańska konferencja poświęcona tematyce wykorzystania komputerów w procesach bibliotecznych. W 1984 r. Biblioteka Uniwersytecka w Mariborze utworzyła przy użyciu komputera pierwszy rekord biblioteczny. Trzy lata później Instytut RCUM (dzisiejszy IZUM) zainicjował system wspólnego katalogowania w formacie COMARC. Biblioteki słoweńskie i biblioteki pozostałych republik ówczesnej SFR Jugosławii połączyły się w System Informacji Naukowych i Technologicznych SNTIJ ${ }^{36}$.

System COBISS w Słowenii rozwija się bez przeszkód od momentu jego powstania. IZUM, instytucja utworzona przez rząd Republiki Słowenii, pełni funkcję serwisu informacyjnego słoweńskiej nauki, kultury i edukacji, odpowiedzialna jest też za implementację systemu COBISS we wszystkich bibliotekach Słowenii.

35 Portali Shtetëror i Republikës së Kosovës, http://www.rks-gov.net [dostęp: 18.07.2016].

${ }^{36}$ M. Seljak, Stanje in problemi avtomatizacije knjižnici v Sloveniji, „Organizacija znanja” 2005, nr 4 (10), s. 248. 
Dynamiczny rozwój bibliotekarstwa słoweńskiego nie został przerwany nawet w momencie rozpadu Jugosławii. Nieprzerwana została edukacja kadr bibliotekarskich, komputeryzacja bibliotek i rozwój sieci COBISS na terenie Słowenii. Rząd Słowenii od lat intensywnie wspiera rozwój bibliotekarstwa w kraju. Wysoki poziom ekonomiczny kraju, dobra organizacja systemu zarządzania funduszami wspierającymi rozwój bibliotekarstwa, zaowocowały imponującą liczbą bibliotek włączonych do systemu COBISS.

W bazie COBISS.SI w 2015 r. funkcjonowało 445 bibliotek, w tym 82 były to biblioteki narodowe, uniwersyteckie i wydziałowe, 61 bibliotek publicznych, 130 bibliotek specjalnych i 172 biblioteki szkolne. Liczba rekordów bibliotecznych w 2015 r. wynosiła 4730086 we wspólnej bazie danych COBISS.SI, natomiast w lokalnych bazach bibliotek słoweńskich $-13306050^{37}$.

W bazie COBISS.SI, oprócz bibliotek znajdujących się na terenie Słowenii, funkcjonują również biblioteki poza granicami kraju: jedna biblioteka w Argentynie, trzy w Austrii i dwie we Włoszech.

Wysoki poziom i tempo rozwoju bibliotek słoweńskich powoduje, że są one przykładem dla innych bibliotek regionu.

\section{Podsumowanie}

Historia rozwoju bibliotek w dawnych republikach jugosłowiańskich pokazuje, jak bardzo rozpad SFRJ, działania wojenne i rozpad całego systemu funkcjonowania społeczeństw negatywnie wpłynęły na kondycję bibliotekarstwa na Półwyspie Bałkańskim. Musiało upłynąć kilka lat, by stworzone zostały warunki do odnowienia stosunków między nowo powstałymi państwami. Silna potrzeba nawiązania współpracy między bibliotekami i kontynuowania rozpoczętych projektów przyczyniły się do odnowienia idei wspólnego opracowywania zbiorów bibliotecznych i stworzenia wspólnego katalogu danych.

Zastosowanie systemu COBISS w większości bibliotek bałkańskich pozwoliło na zacieśnienie stosunków między krajami, nawiązanie współpracy nie tylko w dziedzinie bibliotekarstwa, lecz także na polu nauki, edukacji i kultury.

Korzystanie z programu COBISS połączyło bibliotekarzy oraz przyczyniło się do reaktywowania wspólnej idei rozwoju bibliotekarstwa na Bałkanach i rozwijania ścisłej współpracy ponad podziałami i granicami. Implementacja systemu COBISS w bibliotekach bałkańskich wpływa pozytywnie na rozwój regionu i jego integrację z Unią Europejską.

\footnotetext{
${ }^{37}$ COBISS.SI, http://www.cobiss.si [dostęp: 18.07.2016].
} 


\title{
Bibliografia
}

Bibliotekarstvo: spisanie na Bibliotekarskoto društvo na Makedonija, red. M. Boševski, 2003, nr 21; 2003, nr 1-2; 2006, nr 24; 2007, nr 2.

Bošeski M., Bibliotečno rabotenje vo narodnite biblioteki, Skopje 1991.

Bošeski M., Katalogizacija i sistematizacija na bibliotečen materijal, Skopje 2001.

COBISS.AL, http://www.al.cobiss.net [dostęp: 18.07.2016].

COBISS.BG, http://www.bg.cobiss.net [dostęp: 18.07.2016].

COBISS.CG, http://vbcg.vbcg.me/cobiss [dostęp: 18.07.2016].

COBISS.MK, http://www.vbm.mk/cobiss [dostęp: 18.07.2016].

COBISS.Net, http:// www.cobiss.net/platforma_cobiss.htm [dostęp: 18.07.2016].

COBISS/OPAC: priročnik za uporabnike, Maribor 2002.

COBISS.SI, http://www.cobiss.si [dostęp: 18.07.2016].

COBISS.SR, http://www.vbs.rs/cobiss [dostęp: 18.07.2016].

Djurović J., Stanje avtomatizacije knjižnic v Črni Gori, „Organizacija znanja” 2005, nr 4 (10), s. $230-234$.

dlib.mk, http://www.dlib.mk [dostęp: 18.07.2016].

Gjalevska Ž., Avtomatizacija knjižnic v Makedoniji, „Organizacija znanja” 2005, nr 4 (21), s. 235-240.

Felczak W., Wasilewski T., Historia Jugosławii, Wrocław 1985.

Hajdarović N., Avtomatizacija in knjižnic v BIH, „Organizacija znanja” 2005, nr 4 (10), s. 241-245.

Knjižnica Filozofskog fakulteta Sveučilišta u Zagrebu, http://darhiv.ffzg.unizg.hr [dostęp: 18.07.2016].

Institut informacijskih znanosti IZUM, http://www.izum.si [dostęp: 18.07.2016].

ISBD (M) - Megunaroden standarden bibliografski opis za monografski publikacii, red. L. Gjuzelova Hadži Boškova, Skopje 1975.

Nacionalna i Sveučilišna Knjižnica u Zagrebu, http://www.nsk.hr.

NALIS Foundation, http://www.nalis.bg [dostęp: 18.07.2016].

Osnovna navodila COBISS3: priročnik za uporabnike, Maribor 2001.

Portali Shtetëror i Republikës së Kosovës, http://www.rks-gov.net [dostęp: 18.07.2016].

Seljak M., Stanje in problemi avtomatizacije knjižnici v Sloveniji, „Organizacija znanja” 2005, nr 4 (10), s. 248-252.

Stevanović V., Avtomatizacija knjižnic v Srbiji, „Organizacija znanja” 2005, nr 4 (10), s. 210-218. Vasileva M., Kratko poročilo o stanju avtomatizacije v Nacionalni knjižnici „Sv. Ciril in Metod”, Sofija, ,,Organizacija znanja” 2005, nr 4 (10), s. 246-247.

Verona E., Pravilnik i priručnik za izradbu abecednih kataloga, Zagreb 1986.

\section{Implementation of the COBISS system in the Balkan libraries}

\author{
Summary
}

The beginnings of the computerization of libraries on the Balkan Peninsula involved the implementation of the project SNTIJ (Sistem naučnih i tehnoloških informacija Jugoslavije — System of scientific and technological information of Yugoslavia) in Yugoslav libraries in the 80s of the twentieth century. The creation of an extensive network, unifying library processes, enabled the creation of a common database of bibliographic information. The disintegration of Yugoslavia stopped the process of mutual development and cooperation of libraries in the region. In countries 
formed from the former Yugoslavian republics, continued the development of local library systems based on the COBISS system (Cooperative Online Bibliographic Systems and Services), created by the Institute of Information Science IZUM from Maribor (Slovenia). In the 90s, libraries in newly established countries started using the system COBISS again. The COBISS system was also accepted by libraries in Bulgaria and Albania. The development of the system COBISS, connecting libraries in Balkan countries, allowed the creation of a common information system in the Balkans.

KEYWORDS: COBISS, computerization, Balkan libraries. 